\title{
EVALUATION OF QUALITATIVE AND QUANTITATIVE STABILITY PARAMETERS OF A NEW TABLET FORMULATION CONTAINING BISOPROLOL FUMARATE
}

\author{
ALINA DIANA PANAINTE ${ }^{1}$, GRAȚIELA POPA ${ }^{2 *}$, MĂDĂLINA VIERIU ${ }^{1,}$ NELA BIBIRE $^{1}$, \\ GLADIOLA ȚÂNTARU ${ }^{1}$, ANDREEA CREȚEANU ${ }^{2}$, MIHAI APOSTU ${ }^{1}$ \\ 1 "Grigore T. Popa" University of Medicine and Pharmacy, Faculty of Pharmacy, Department of Analytical Chemistry, 15 \\ Universității Street, 700115, Iași, Romania \\ 2 "Grigore T. Popa" University of Medicine and Pharmacy, Faculty of Pharmacy, Department of Pharmaceutical \\ Technology, 15 Universității Street, 700115, Iași, Romania
}

*corresponding author: gratielapopa@yahoo.com

Manuscript received: December 2017

\begin{abstract}
Formulations that are able to modulate drug release have become an integral part of the pharmaceutical industry. The stability of the newly developed formulations depends on the physico-chemical properties of the associated substances and on various other external factors. The stability of a drug implies that its properties may change within controlled and acceptable limits. The main objective of the present study was to evaluate the qualitative and quantitative parameters of modified release tablets of bisoprolol fumarate (BF) formulated using hydroxypropyl methylcellulose and Precirol ATO5 excipients. $20 \mathrm{mg}$ BF tablets were prepared through melt granulation technique using Precirol ATO5 as binder. The results of storage-stability tests showed that the obtained tablets were stable under stress condition $\left(40 \pm 2{ }^{\circ} \mathrm{C}, \mathrm{RH} 75 \pm 5 \%\right)$ for at least 6 months and did not show any significant changes regarding their appearance and drug content.
\end{abstract}

\section{Rezumat}

Formulările capabile să moduleze eliberarea substanței medicamentoase au devenit o parte integrantă a industriei farmaceutice. Stabilitatea formulărilor nou dezvoltate depinde de proprietățile fizico-chimice ale substanțelor asociate, dar și de diverși factori externi. Stabilitatea unui medicament implică faptul că proprietățile sale se pot schimba în limite controlate şi acceptabile. Obiectivul principal al prezentului studiului a constat în evaluarea parametrilor calitativi şi cantitativi ai comprimatelor cu eliberare modificată cu $20 \mathrm{mg}$ bisoprolol fumarat și excipienți precum hidroxipropil metilceluloză şi Precirol ATO5. Comprimatele cu bisoprolol fumarat au fost preparate prin tehnica granulării prin topire (melt granulation), folosind Precirol ATO5 ca liant. Rezultatele testelor de stabilitate au demonstrat stabilitatea comprimatelor obținute în condiții de stres $\left(40 \pm 2^{\circ} \mathrm{C}\right.$, RH $\left.75 \pm 5 \%\right)$ cel puțin 6 luni și acestea nu au prezentat modificări semnificative privind aspectul şi conţinutul de substanță activă.

Keywords: bisoprolol fumarate, hydroxypropyl methylcellulose, Precirol ATO5, stability study

\section{Introduction}

Oral drug administration is the most popular drug delivery route. Innovative formulations for controlled drug release have become an essential part of oral dosage forms technology, due to their costeffectiveness, reduced risk of systemic toxicity and of dose dumping. The stability of the newly developed formulations depends on the physico-chemical properties of the associated substances and various external factors [1]. The stability of a drug implies that its properties may change within controlled and acceptable limits. There are two ways to determine the shelf life of a drug product: experimental studies performed under normal long-term storage conditions and experimental determinations done under short-term intensive and constantly demanding conditions. One of the least complicated approaches to the manufacture of sustained release dosage forms involves embedding the drug within the retardant material, combining it with other excipients, followed by compression.

Bisoprolol fumarate $(\mathrm{BF})$ is a beta blocker widely prescribed for the treatment of hypertension and angina. It is highly water soluble, with a bioavailability of $80 \%$, due to its first pass metabolism and a clearance half-life of $3.5 \mathrm{~h}$ [3]. Therefore, BF requires multiple daily doses in order to maintain adequate plasma concentrations, which makes it a suitable candidate for modified drug delivery formulations [8]. Precirol ${ }^{\circledR}$ ATO5 (Prec) is a multifunctional excipient: a sustained release agent, lubricant and taste masking agent for oral dosage formulations [15]. It is suitable for melt processing techniques and is an effective problem solver in case of chemical incompatibilities. It has binding properties without affecting tablet hardness 
and is not influenced by mixing/production parameters [9]. Hydroxypropyl methylcellulose (HPMC) has excellent thickening, emulsifying, film forming, protective colloid properties $[10,11]$. It has been widely used in the development of new modified release formulations: mucoadhesive formulations, controlled-release pellets, microcapsules and tablets, multi-layered sustained-release tablets, coated sustainedrelease formulations, sustained-release ophthalmic preparations and suppositories [12]. The objective of these studies was to evaluate the qualitative and quantitative parameters of new tablets containing bisoprolol fumarate in order to acquire data on how the qualities of the drug and of the obtained dosage form undergo changes over time under the influence of various environmental factors.

\section{Materials and Methods}

Materials. Bisoprolol fumarate - 99.98\% purity (BSP Unichem Laboratories LTD, India), glyceryl distearate as Precirol ATO5 (kindly offered by Gatefossé), hydroxypropyl methylcellulose (HPMC K4M, 4000 cps, Premium, Colorcon).

Methods. The preparation of $20 \mathrm{mg}$ BF tablets was performed using the melt granulation technique using Precirol ATO5 as binder. [2]. The powders (bisoprolol fumarate, Precirol ATO5 and HPMC) were mixed and heated to $65^{\circ} \mathrm{C}$; the obtained mass was passed through a $500 \mu \mathrm{m}$ sieve, the granules were obtained upon cooling and further compressed on a Korsch EK0 tablet press (9 mm flat punches). Identification and determination of the bisoprolol fumarate content

The qualitative and quantitative evaluation of the active substance in the new tablets was performed using a HPLC method with the characteristics presented in Table I.

The following solutions were prepared: the reference solution was obtained by dissolving $25 \mathrm{mg} \mathrm{BF}$ reference substance in $50 \mathrm{~mL}$ mobile phase; the sample solution: 20 tablets were triturated. An amount of powder corresponding to $50 \mathrm{mg}$ bisoprolol was brought to $100 \mathrm{~mL}$ into a volumetric flask with mobile phase. After stirring for 30 minutes, $10 \mathrm{~mL}$ of supernatant was diluted to $100 \mathrm{~mL}$ with the same solvent and filtered. The bisoprolol content was calculated using the formula:

$$
\mathrm{mg} \frac{\mathrm{BF}}{\text { tablet }}=\frac{\mathrm{A}_{\mathrm{p}}}{\mathrm{A}_{\mathrm{R}}} * \mathrm{c}_{\mathrm{R}} * \frac{\mathrm{B}_{\mathrm{c}}}{\mathrm{a}} * \mathrm{D} * \mathrm{~m} * 10^{-2},
$$

where: $A_{P} \& A_{R}=$ the peak areas of $B F$ in the sample and reference solution, $C_{R}=B F$ reference solution concentration $(\mathrm{mg} / \mathrm{mL})$, where $B_{C}=$ content of $\mathrm{BF}$ reference substance $(\%), \mathrm{a}=$ the amount of powder analysed $(\mathrm{mg})$ and $\mathrm{m}=$ mean tablet mass (mg). Admissibility: $18.00-22.00 \mathrm{mg} \mathrm{BF/tablet.}$

Table I

HPLC characteristics

\begin{tabular}{|c|c|}
\hline Instrument & Agilent 1200 Series \\
\hline Chromatographic column & Agilent Eclipse XDB-C18 $150 \mathrm{~mm} \times 4.6 \mathrm{~mm}, 5 \mu \mathrm{m}$ \\
\hline Column temperature & $25^{\circ} \mathrm{C}$ \\
\hline Mobile phase & pH 5.5 phosphate buffer: acetonitrile $(90: 10, \mathrm{v} / \mathrm{v})$ \\
\hline Flow & $1 \mathrm{~mL} / \mathrm{min}$ \\
\hline Detection & $225 \mathrm{~nm}$ \\
\hline Automated injection volume & $25 \mu \mathrm{L}$ \\
\hline Autosampler temperature & $20^{\circ} \mathrm{C}$ \\
\hline
\end{tabular}

The method validation consisted in evaluating the following parameters of linearity, quantitative and detection limits, accuracy, precision and selectivity $[6,13,14]$.

The analysis of related substances. The related substances were also determined using the HPLC method described above, by testing the following solutions: the sample solution was prepared as previously described. The working solution 1: 2.5 $\mathrm{mL}$ of the sample solution was diluted with mobile phase up to $25 \mathrm{~mL}$, and then $1 \mathrm{~mL}$ was transferred into a $100 \mathrm{~mL}$ volumetric flask with the same solvent. The working solution 2: $2.5 \mathrm{~mL}$ of the sample solution was diluted with mobile phase up to $25 \mathrm{~mL}$, and then $5 \mathrm{~mL}$ was transferred into a $100 \mathrm{~mL}$ volumetric flask with the same solvent.

Equal volumes of previously described solutions were subjected to the HPLC analysis, and the corresponding chromatograms were recorded. The elution time of the sample solution was double than the retention time of BF. The peak area of each impurity should not exceed the peak area corresponding to the working solution $1(0.1 \%)$, and the sum of the areas of all secondary peaks should not exceed the area of the main peak obtained for the work solution 2 $(0.5 \%)[5,7]$. The area of any secondary peak should not exceed 0.1 of the main peak area obtained for solution $2(0.05 \%)$. The peak corresponding to fumaric acid should be disregarded.

Uniformity of dosage units. Uniformity of dosage units was evaluated according to the European Pharmacopoeia (Eur. Ph.) [4]. The drug content was determined on a representative sample by applying the procedure used for the analysis of related substances. The results were expressed as percentage of the declared content (A). The mean 
tablet mass $(\bar{m})$ was determined on 10 tablets. The $\mathrm{BF}$ content was estimated based on the formula:

$$
\mathrm{x}_{\mathrm{i}}=\mathrm{w}_{\mathrm{i}} * \frac{\mathrm{A}}{\overline{\mathrm{m}}} \text {. }
$$

The standard deviation of the contents and the acceptance value were calculated. Interpretation of the results was carried out in accordance with the Eur. Ph [4], which stipulates that the acceptability value for 10 dosage units should be less than or equal to $\mathrm{L} 1(\mathrm{~L} 1=15)$. If the acceptance value is higher than L1, the determination must be repeated on 20 tablets.

Microbial contamination. Microbial contamination was evaluated according to Eur. Ph. [4] as the total number of aerobic bacteria, the total number of microorganisms, and the total number of fungi. Determination of the total number of aerobic bacteria and that of fungi was done by plate counting. Determination of specific microorganisms was performed using the selective media method. The Escherichia coli test was performed on 3 types of culture media according to Eur. Ph.

Evaluation of tablet stability. Long-term and shortterm stability tests were performed at $25 \pm 2{ }^{\circ} \mathrm{C}$, and at $40 \pm 2{ }^{\circ} \mathrm{C}$ and $75 \pm 5 \%$ humidity, respectively, for accelerated aging, over a 3 month period, in accordance with the current legislation. For the assessment of tablets shelf-life, the long-term isothermal process was based on the drug degradation rate $[7,16]$. The mathematical model of $\mathrm{BF}$ degradation was established based on the interpolation of experimental data.

The storage period was established through a graphical method that stated that the stability period is set by intersecting the regression equation curve with the straight line corresponding to the minimum specification provided by Eur. Ph. for drug content, or the maximum specified for the degradation products. Three series of tablets were tested.

\section{Results and Discussion}

The linearity of the HPLC method used in the study was tested over the $0.5-20 \mu \mathrm{g} / \mathrm{mL}$ range, and the calibration curve was obtained by plotting the $\mathrm{BF}$ concentration against the peak area. The detector response was linear with respect to $\mathrm{BF}$ concentration. The correlation coefficient value was 0.9983, in accordance to the acceptability criteria.

Accuracy and precision were tested by analysing six samples with theoretical concentrations of 2,8 , $15 \mu \mathrm{g} / \mathrm{mL}$, with experimental results ranging from 96.75 to $103.65 \%$ for precision and $0.376-2.130$ for accuracy, thus fulfilling the admissibility criteria [6]. Selectivity was achieved by injecting a mixture containing, besides the drug, the excipients used for compression. No significant interference was observed regarding $\mathrm{BF}$.

Retention times corresponding to fumaric acid, $\mathrm{BF}$, impurities A, B, C are shown in Table II. The required values for other individual impurities are max. $0.10 \%$ and the result obtained was $0.06 \%$, within the required limits. The required total impurity value was $0.30 \%$, which was appropriate as it was within the max. $0.50 \%$ required limits. The results obtained for the BF related impurities fell within the required limits $[5,16]$. Table III presents the results obtained for the qualitative and quantitative parameters of the $20 \mathrm{mg}$ BF tablets.

Table II

Retention times of BF and impurities

\begin{tabular}{|l|c|c|}
\hline \multicolumn{1}{|c|}{ Component } & Retention time (min) & Relative retention time (min) \\
\hline Fumaric acid & 1.1 & 0.13 \\
\hline Impurity A & 1.5 & 0.17 \\
\hline Impurity B & 2.0 & 0.23 \\
\hline Impurity C & 3.4 & 0.38 \\
\hline $\mathrm{BF}$ & 4.5 & 0.52 \\
\hline
\end{tabular}

Table III

Physico-chemical and microbiological properties of the $20 \mathrm{mg}$ BF tablets

\begin{tabular}{|c|c|c|}
\hline Parameter & Admissibility & Results \\
\hline Appearance & White, flat, uniformly shaped tablets, intact edges & Met the requirements \\
\hline BF identification & $\begin{array}{l}\text { The main peak on the chromatogram obtained for the sample } \\
\text { solution must show the same retention time with the main } \\
\text { peak in the chromatogram for the reference solution }\end{array}$ & Met the requirements \\
\hline BF content (mg/tablet) & $18.50-21.50$ & 19.66 \\
\hline $\begin{array}{l}\text { Related substances: } \\
\text { - Individual, } \max \% \\
\text { - Amount, } \max \%\end{array}$ & $\begin{array}{l}0.1 \\
0.5\end{array}$ & $\begin{array}{l}0.092 \\
0.151\end{array}$ \\
\hline Uniformity of dosage units & According to Eur. $\mathrm{Ph}$ & Meet the requirements \\
\hline Average weight (mg/tablet) & $138.75-161.25$ & 150.18 \\
\hline
\end{tabular}


FARMACIA, 2018, Vol. 66, 3

\begin{tabular}{|l|c|c|}
\hline \hline \multicolumn{1}{|c|}{ Parameter } & Admissibility & Results \\
\hline Microbial contamination & max. $10^{3}$ & 22 \\
- no. total aerobic bacteria/g & max. $10^{2}$ & $<1$ \\
- no. total aerobic fungi/g & absent & \\
- Escherichia coli & . & \\
\hline
\end{tabular}

The results for the long-term tests on three product series, as well as the average values of the qualitative and quantitative parameters evaluated are presented in Tables IV and V.
After12 months of storing at $25^{\circ} \mathrm{C}$ in PVC-aluminum packaging, the $\mathrm{BF} \mathrm{mg} /$ tablet content dropped by less than $3.7 \%$ and the appearance of the tablets remained the same.

Table IV

Qualitative and quantitative evaluation results of the $20 \mathrm{mg} \mathrm{BF}$ tablets at $25^{\circ} \mathrm{C}$

\begin{tabular}{|c|c|c|c|c|c|c|}
\hline \multicolumn{2}{|r|}{ Parameter Time } & O months & 3 months & 6 months & 9 months & 12 months \\
\hline & Description, appearance & \multicolumn{5}{|c|}{ White, round, uniformly-shaped tablets, intact edges } \\
\hline \multirow{2}{*}{ 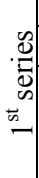 } & BF content (mg/tablet) & 20.001 & 19.941 & 19.859 & 19.758 & 19.697 \\
\hline & $\begin{array}{l}\text { Related substances: } \\
\text { - Individual, max\% } \\
\text { - Amount, } \max \%\end{array}$ & $\begin{array}{c}\text { Met the } \\
\text { requirements } \\
0.148\end{array}$ & $\begin{array}{c}\text { Met the } \\
\text { requirements } \\
0.198\end{array}$ & $\begin{array}{c}\text { Met the } \\
\text { requirements } \\
0.231\end{array}$ & $\begin{array}{c}\text { Met the } \\
\text { requirements } \\
0.273\end{array}$ & $\begin{array}{c}\text { Met the } \\
\text { requirements } \\
0.320\end{array}$ \\
\hline \multirow{3}{*}{ 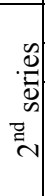 } & Description, appearance & \multicolumn{5}{|c|}{ White, round, uniformly-shaped tablets, intact edges } \\
\hline & BF content (mg/tablet) & 19.936 & 19.809 & 19.585 & 20.002 & 19.901 \\
\hline & $\begin{array}{l}\text { Related substances: } \\
\text { - Individual, } \max \% \\
\text { - Amount, } \max \%\end{array}$ & $\begin{array}{c}\text { Met the } \\
\text { requirements } \\
0.149 \\
\end{array}$ & $\begin{array}{c}\text { Met the } \\
\text { requirement } \\
0.201 \\
\end{array}$ & $\begin{array}{c}\text { Met the } \\
\text { requirements } \\
0.235 \\
\end{array}$ & $\begin{array}{c}\text { Met the } \\
\text { requirements } \\
0.264 \\
\end{array}$ & $\begin{array}{c}\text { Met the } \\
\text { requirements } \\
0.321 \\
\end{array}$ \\
\hline & Description, appearance & \multicolumn{5}{|c|}{ White, round, uniformly-shaped tablets, intact edges } \\
\hline 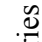 & BF content (mg/tablet) & 19.986 & 19.958 & 19.855 & 19.753 & 19.698 \\
\hline D্ & $\begin{array}{l}\text { Related substances: } \\
\text { - Individual, max\% } \\
\text { - Amount, } \max \%\end{array}$ & $\begin{array}{c}\text { Met the } \\
\text { requirements } \\
0.147\end{array}$ & $\begin{array}{c}\text { Met the } \\
\text { requirements } \\
0.202\end{array}$ & $\begin{array}{c}\text { Met the } \\
\text { requirements } \\
0.233\end{array}$ & $\begin{array}{c}\text { Met the } \\
\text { requirements } \\
0.284\end{array}$ & $\begin{array}{c}\text { Met the } \\
\text { requirements } \\
0.325\end{array}$ \\
\hline
\end{tabular}

Table V

Quantitative parameters of $20 \mathrm{mg}$ BF tablets change over time

\begin{tabular}{|l|c|c|c|c|c|}
\hline \multicolumn{1}{|c|}{ Time (months) } & 0 & 3 & 6 & 9 & 12 \\
\hline BF content (mg/tablet) & 19.974 & 19.873 & 19.785 & 19.718 & 19.682 \\
\hline $\begin{array}{c}\text { Related substances } \\
\text { - Amount, max\% }\end{array}$ & 0.147 & 0.194 & 0.258 & 0.287 & 0.329 \\
\hline Logarithm of BF content & 1.301 & 1.299 & 1.297 & 1.2952 & 1.294 \\
\hline
\end{tabular}

By plotting the time variation against the logarithm of the concentration of bisoprolol fumarate ( $\mathrm{mg} /$ tablet), the curve in Figure 1 shows that drug degradation is of $1^{\text {st }}$ order. The delineation of the degradation was

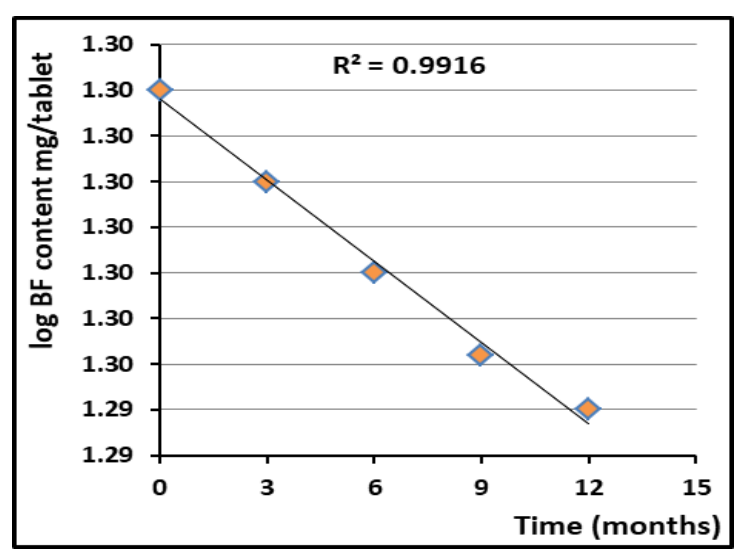

Figure 1.

Degradation curve of $\mathrm{BF}$ at $25^{\circ} \mathrm{C}$ performed by experimental data interpolation, resulting in the regression curve:

$$
\log \mathrm{c}=-0.0006 \times \mathrm{t}+1.3008
$$

where: $\mathrm{c}=\mathrm{BF}$ content $(\mathrm{mg} /$ tablet $)$ and $\mathrm{t}=$ time (months).

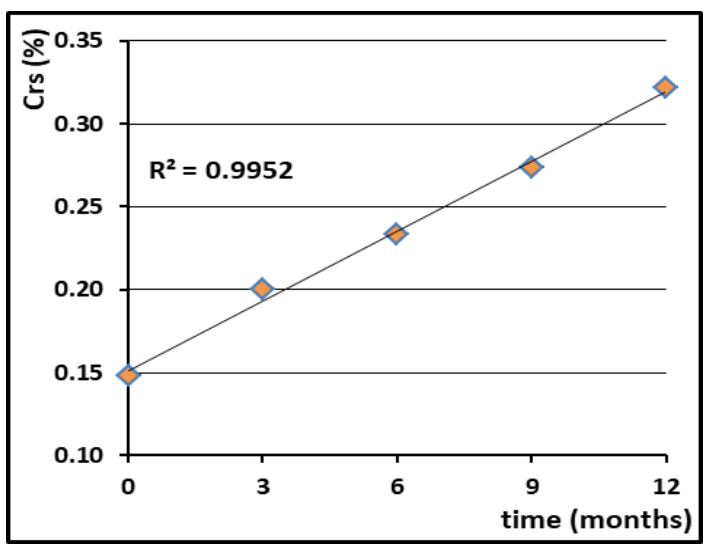

Figure 2.

Increasing content of content of related substances $\left(\mathrm{C}_{\mathrm{rs}}\right)$ at $25^{\circ} \mathrm{C}$ 
FARMACIA, 2018, Vol. 66, 3

The adequacy analysis took into account 2 degrees of freedom. The experimental $\left(\mathrm{y}_{\exp }\right)$ and calculated values $\left(\mathrm{y}_{\text {calc }}\right)$ for $\mathrm{BF}$ content based on the regression equation are shown in Table VI.

Table VI

Experimental and calculated values for BF $20 \mathrm{mg} / \mathrm{tablet}$

\begin{tabular}{|c|c|c|c|c|c|}
\hline $\mathbf{X}$ & $\mathbf{0}$ & $\mathbf{3}$ & $\mathbf{6}$ & $\mathbf{9}$ & $\mathbf{1 2}$ \\
\hline $\mathrm{y}_{\exp }$ & 19.974 & 19.873 & 19.785 & 19.718 & 19.682 \\
\hline $\mathrm{y}_{\text {calc }}$ & 19.965 & 19.845 & 19.789 & 19.709 & 19.678 \\
\hline
\end{tabular}

The experimental data dispersion due to the error of experience $\left(s_{1}^{2}\right)$ and the values calculated based on the mathematical model $\left(s_{2}^{2}\right)$ were: $s_{1}^{2}=0.002612$ and $s_{2}^{2}=0.000523$. The Fischer test value was:

$$
\mathrm{F}_{\text {calc }}=\frac{\mathrm{s}_{2}^{2}}{\mathrm{~s}_{1}^{2}}=0.20 \text {. }
$$

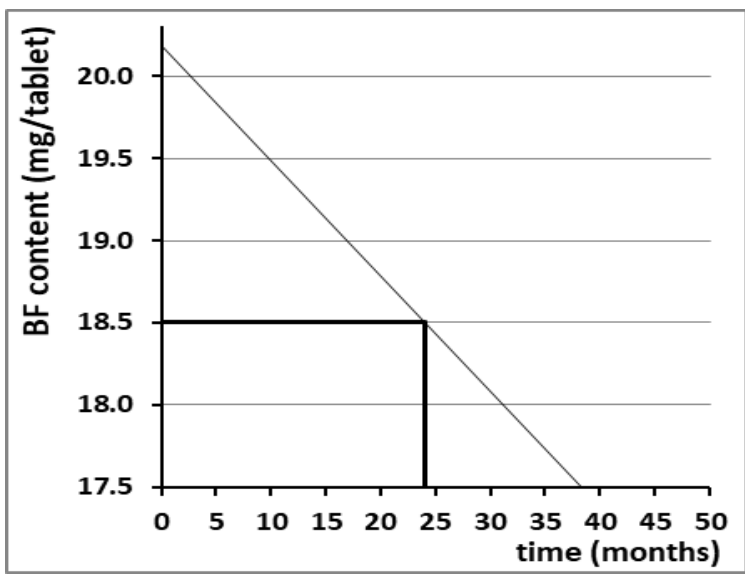

\section{Figure 3.}

Graphical evaluation of the shelf life of BF tablets at $25^{\circ} \mathrm{C}$

The results of the isothermal test at $40 \pm 2{ }^{\circ} \mathrm{C}$ and $75 \pm$ $5 \%$ relative humidity for 6 months on three product series are shown in Tables VII and VIII. Under
The critical value for the Fischer distribution for a $95 \%$ accuracy was $\mathrm{F}(95 \%, 2.2)=19$. Because $\mathrm{F}_{\text {calc }}$ $<\mathrm{F}(95 \%, 2.2)$ it was proved that the chosen model was suitable for a $95 \%$ confidence interval $[9,11]$. The content of related substance $\left(\mathrm{C}_{\mathrm{rs}}\right)$ was expressed as the sum of all peak areas for related substances, max. \% may be assimilated after a zero order kinetics described by the equation obtained on the curve of Figure 2.

$$
\mathrm{C}_{\mathrm{rS}}=0.014 \times \mathrm{t}+0.1511 \text {; }
$$

where: $C_{r s}=$ related substances content and $t=$ time (months).

Analysing the graphs shown in Figure 3, the stability period of the $20 \mathrm{mg} \mathrm{BF}$ tablets stored in PVC-aluminium packaging at $25^{\circ} \mathrm{C}$, could be assessed at 24.1 months for a $95 \%$ probability and for an $18.5 \mathrm{mg} /$ tablet BF minimum content.

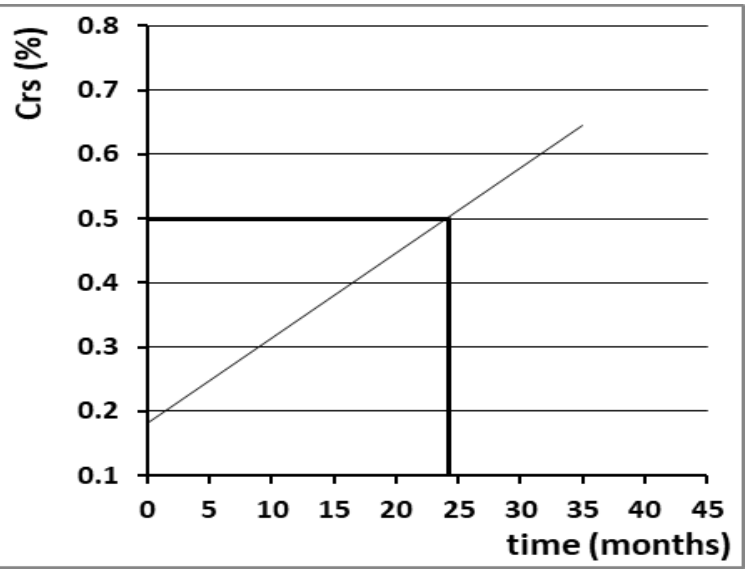

these conditions, the BF content drops by maximum $6.45 \%$. The appearance of the tablets did not change during the preservation period.

Table VII

\begin{tabular}{|c|c|c|c|c|c|}
\hline \multicolumn{2}{|c|}{$\begin{array}{ll}\text { Parameter } & \text { Time } \\
\end{array}$} & 0 months & 1 month & 3 months & 6 months \\
\hline \multirow{3}{*}{ 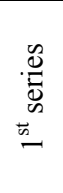 } & Description, appearance & \multicolumn{4}{|c|}{ White, round, uniformly-shaped tablets, intact edges } \\
\hline & BF content $\mathrm{mg} /$ tablet & 20.020 & 19.831 & 19.639 & 19.358 \\
\hline & $\begin{array}{l}\text { Related substances: } \\
\text { - Individual, max\% } \\
\text { - Amount, } \max \%\end{array}$ & $\begin{array}{c}\text { Met the } \\
\text { requirements } \\
0.285\end{array}$ & $\begin{array}{c}\text { Met the } \\
\text { requirements } \\
0.303\end{array}$ & $\begin{array}{c}\text { Met the } \\
\text { requirements } \\
0.333\end{array}$ & $\begin{array}{c}\text { Met the } \\
\text { requirements } \\
0.404\end{array}$ \\
\hline \multirow{3}{*}{ 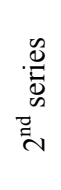 } & Description, appearance & \multicolumn{4}{|c|}{ White, round, uniformly-shaped tablets, intact edges } \\
\hline & $\mathrm{BF}$ content $\mathrm{mg} / \mathrm{tablet}$ & 19.989 & 19.842 & 19.515 & 19.320 \\
\hline & $\begin{array}{l}\text { Related substances: } \\
\text { - Individual, } \max \% \\
\text { - Amount, } \max \%\end{array}$ & $\begin{array}{c}\text { Met the } \\
\text { requirements } \\
0.279\end{array}$ & $\begin{array}{c}\text { Met the } \\
\text { requirements } \\
0.305\end{array}$ & $\begin{array}{c}\text { Met the } \\
\text { requirements } \\
0.375\end{array}$ & $\begin{array}{l}\text { Met the } \\
\text { requirements } \\
0.424\end{array}$ \\
\hline \multirow{3}{*}{ 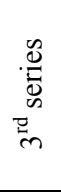 } & Description, appearance & \multicolumn{4}{|c|}{ White, round, uniformly-shaped tablets, intact edges } \\
\hline & $\mathrm{BF}$ content $\mathrm{mg} /$ tablet & 20.006 & 19.918 & 19.615 & 19.223 \\
\hline & $\begin{array}{l}\text { Related substances: } \\
\text { - Individual, } \max \% \\
\text { - Amount, } \max \%\end{array}$ & $\begin{array}{c}\text { Met the } \\
\text { requirements } \\
0.283\end{array}$ & $\begin{array}{c}\text { Met the } \\
\text { requirements } \\
0.299\end{array}$ & $\begin{array}{c}\text { Met the } \\
\text { requirements } \\
0.331\end{array}$ & $\begin{array}{c}\text { Met the } \\
\text { requirements } \\
0.383\end{array}$ \\
\hline
\end{tabular}

Qualitative and quantitative evaluation of $20 \mathrm{mg} \mathrm{BF}$ tablets at $40^{\circ} \mathrm{C}$ 
Changes of quantitative parameters of the $20 \mathrm{mg}$ BF tablets as average values over time

\begin{tabular}{|l|c|c|c|c|}
\hline Time (months) & 0 & 1 & 3 & 6 \\
\hline BF content (mg/tablet) & 20.002 & 19.796 & 19.579 & 19.251 \\
\hline Related substances amount (max\%) & 0.282 & 0.302 & 0.345 & 0.402 \\
\hline
\end{tabular}

By interpolation of experimental data the following regression equations were obtained (Figure 4 and 5) for the decrease of BF content:

$$
\mathrm{C}=0.0083 \times \mathrm{t}^{2}-0.1209 \times \mathrm{t}+9.9985 ;
$$

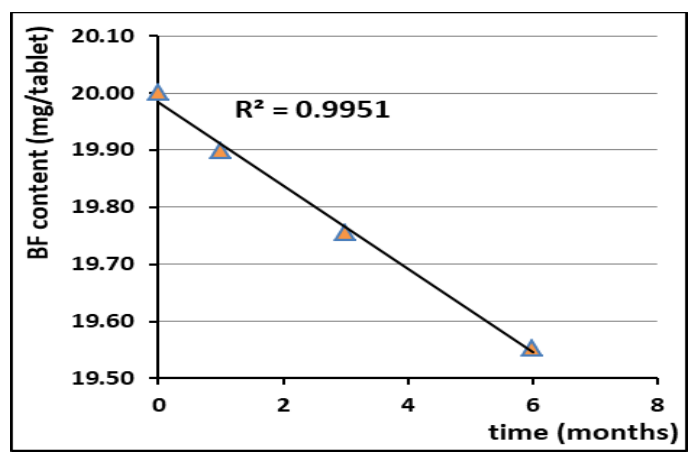

Figure 4.

BF Degradation curve at $40^{\circ} \mathrm{C}$

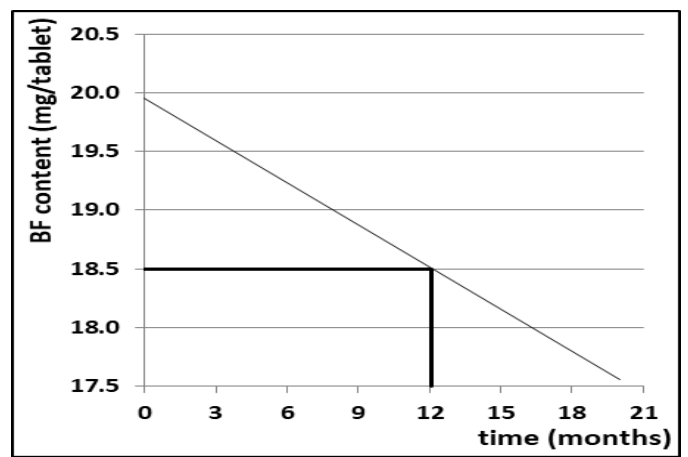

Figure 6.

Graphical evaluation of the stability period of BF tablets at $40^{\circ} \mathrm{C}$ where: $\mathrm{C}=\mathrm{BF}$ content $(\mathrm{mg} /$ tablet $)$, and $\mathrm{t}=$ time (months) and for $\mathrm{C}_{\mathrm{rs}}$ :

$$
\mathrm{C}_{\mathrm{rs}}=0.02535 \times \mathrm{t}+0.277 \text {; }
$$

where: $\mathrm{C}_{\mathrm{rs}}=$ content of related substances, $(\max \%)$, and $\mathrm{t}=$ time (months).

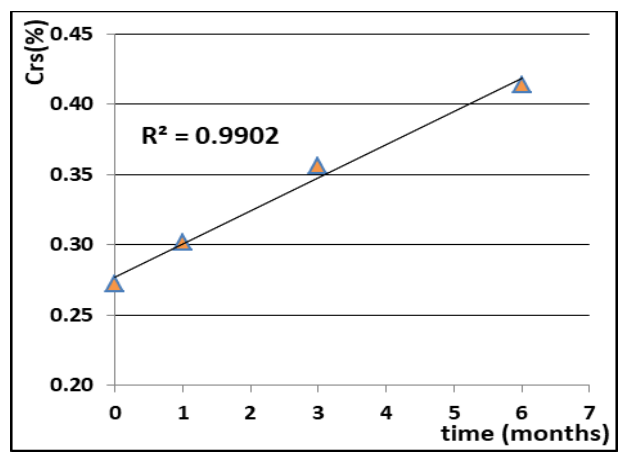

Figure 5.

Related substances content increase at $40^{\circ} \mathrm{C}$

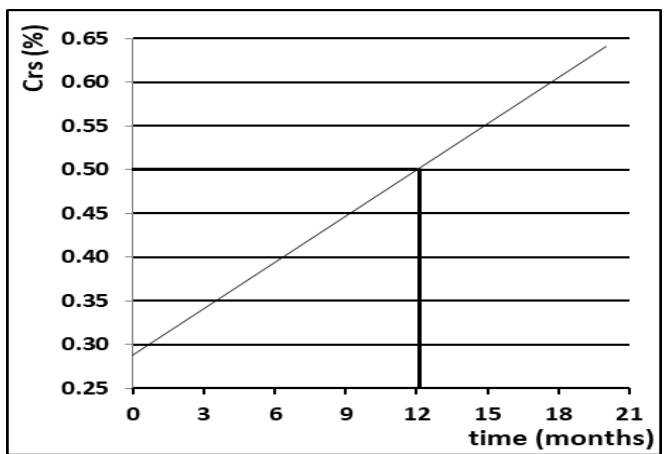

tablets did not show any significant change in appearance and drug content throughout the tested stability period. Furthermore, the newly developed tablets were stable for at least 6 months under stress conditions. Stability tests were carried to ensure that the tablets were stable throughout their shelf life in accordance with $\mathrm{ICH}$ requirements.

\section{References}

1. Ankit A, Gulzar AM., Vinay $\mathrm{CH}$, Sanjana A, Formulation approach to improve the gastric residence time of bisoprolol fumarate by gastroretentive tablets. $J$ Pharm Res., 2015; 14(4): 94-97.

2. Desai US, Chaudhari PD, Bhavsar DB, Chavan RP, Melt granulation: an alternative to traditional granulati on techniques. Indian Drugs, 2013; 50(3): 5-13.

3. Deshmukh ND, Phadtare G, Nilesh B, Asawa M, Formulation and evaluation of bisoprolol fumarate 
fast dissolving tablet by direct compression techniques. IJPRBS, 2012; 1(5): 364-378.

4. European Pharmacopoeia 7th Edition. European Directorate for the Quality of Medicines \& HealthCare, Strasbourg, 2015.

5. Gorog S, Identification and determination of impurities in drugs. Elsevier Science B.V. Publisher, Amsterdam, 2000.

6. ICH Harmonised Tripartite Guideline Q2(R1). Validation of analytical procedures, 2005.

7. ICH Topic Q1A(R2), Stability testing of new drug substances and products, 2009.

8. Jagdale SC, Bari NA, Kuchekar BS, Chabukswar AR, Optimization studies on compression coated floating-pulsatile drug delivery of bisoprolol. Bio Med Res., 2013; 2013: 1-11.

9. Jannin V, Pochard E, Chambinb O, Influence of poloxamers on the dissolution performance and stability of controlled-release formulations containing Precirol ${ }^{\circledR}$ ATO5. Int J Pharm., 2006; 309: 6-15.

10. Levina MM, Rajabi-Siahboomi AR, The Influence of excipients on drug release from hydroxypropyl methylcellulose matrices. J Pharm Sci., 2004; 93(11): 2747-2754.
11. Li CL., Martini LG, Ford JL, Roberts M, The use of hypromellose in oral drug delivery. J. Pharm. Pharmacol., 2005; 57(5): 533-546.

12. Mahu SC, Spac AF, Ciobanu C, Hancianu M, Agoroaei L, Butnaru E, Quantitative determination of bisoprolol fumarate by HPLC I. Method validation. Rev Chim (Bucharest), 2016; 67(3): 414-417.

13. Panainte AD, Agoroaei L, Bibire N, Tantaru G, Apostu M, Vieriu M, A HPLC Method for the determination of bisoprolol in tablets and its application to a bioequivalence study. Rev Chim (Bucharest), 2015; 66 (11): 1791-1795.

14. Phadtare D, Phadtare G, Nilesh B, Asawa M, Hypromellose - a choice of polymer in extended release tablet formulation. SJIF, 2014; 3(9): 551556.

15. Șaramet G, Rădulescu FȘ, Miron DS, Bărbuceanu ŞF, Stănescu AA, Vlaia L, Piţuru S, Lupuliasa D, Study describing the formulation and the release of some active pharmaceutical ingredients from HPMC hydrophilic matrix tablets. Note I. Farmacia, 2017; 65(5): 690-697.

16. Sumie Y, Valentino JS, Stability of drugs and dosage forms. Springer, Boston, 2002. 